\title{
PROFESIONALNI IDENTITET UČITELJA FRANCUSKOGA JEZIKA U REPUBLICI HRVATSKOJ
}

\section{Rea Lujić}

Odjel za francuske i frankofonske studije, Sveučilište u Zadru, Hrvatska rlujic@unizd.hr

Identitet učitelja inoga jezika nedovoljno je istražen koncept na području Republike Hrvatske. Stoga se u ovome radu navedeni koncept ponajprije teorijski razmatra, a potom se prikazuju rezultati istraživanja profesionalnog identiteta učitelja francuskoga jezika u RH. $U$ istraživačkome dijelu rada razmatramo mijenjaju li učitelji francuskog jezika svoj profesionalni identitet ili ne mijenjaju, a ako mijenjaju, $u$ kojoj je to mjeri i koji su razlozi tomu. Rezultati su pokazali kako učitelji svoj učiteljski identitet najčešće mijenjaju sudjelujući na lokalnim stručnim usavršavanjima, a najmanje sudjelovanjem u organiziranim e-tečajevima. Glavnim razlogom za sudjelovanje u aktivnostima stručnoga usavršavanja pokazao se njihov unutarnji poticaj, dok su se glavnim razlogom za nesudjelovanjem pokazali financijski čimbenici. Dulje radno iskustvo, članstvo u Hrvatskoj udruzi profesora francuskoga jezika i obvezni status jezika pokazali su se faktorima koji statistički značajno pozitivno utječu na osjećaj pripadnosti zajednici učitelja francuskoga jezika u Republici Hrvatskoj.

Ključne riječi: Hrvatska, identitet učitelja inoga jezika, učitelj francuskog jezika, ulaganje, stručno usavršavanje, sudjelovanje

\section{Uvod}

Posljednja dva desetljeća područje istraživanja ovladavanja inim jezikom obilježeno je znatnim porastom zanimanja za identitet inojezičnoga učenika (vidi Norton-Peirce, 1995; Pavlenko i Blackledge, 
2004; Miller, 2004; Block, 2007; Norton i Toohey, 2011; Duff, 2012). Sve je veći broj istraživanja koja se bave identitetom učitelja inoga jezika (vidi Duff i Uchida, 1997; Pavlenko, 2003; Varghese et al., 2005; Clarke, 2008; Reeves, 2009; Kanno i Stuart, 2011; Menard-Warwick, 2013; Stranger-Johanssen i Norton, 2017). Važnost teme ogleda se i u posebnom broju uglednoga jezikoslovnoga časopisa The Modern Language Journal (2017) posvećenog upravo identitetu učitelja inoga jezika. Među hrvatskim glotodidaktičarima identitetom inojezičnoga učitelja bavi se tek nekolicina autora $i$ to njegovim pojedinim vidovima, prvenstveno profesionalnim kompetencijama i učiteljskim ulogama (vidi Vrhovac i Berlengi, 2010; Cindrić, Andraka i Bilić-Štefan, 2014; Breka i Petravić, 2015; Petravić, 2015; Petravić i Šenjug-Golub, 2016; Knežević, 2017; Lujić, 2017, 2018).

Jedan od razloga zbog kojih se učiteljevom identitetu pridaje sve veća važnost vjerojatno odražava promjene nastale u predodžbi složenosti učiteljskoga zanimanja. Naime, učitelji inoga jezika donedavno su smatrani običnim »tehničarima koji trebaju primijeniti odgovarajuću metodu kako bi učenici ovladali ciljnim jezikom« (Varghese et al., $2005,22)$. U skladu s tim pogledom, učiteljev identitet istraživao se molekularno (npr. stavovi, vjerovanja, kompetencije) te su takva istraživanja učitelja i kontekst ovladavanja inim jezikom prikazivala prilično pojednostavljeno, jednodimenzionalno i statično. Za razliku od molekularnog pristupa istraživanju, molarni pristup, tipičan za društvenu paradigmu $^{1} \mathrm{u}$ obzir uzima cjelokupni učiteljev identitet što podrazumijeva i utjecaj društveno-kulturnoga konteksta na oblikovanje identiteta te omogućuje bolje razumijevanje učitelja, što je jedan od preduvjeta za razumijevanje učenja i poučavanja (Varghese et al., 2005) te međuovisnosti učiteljeva identiteta i djelovanja koja se zbivanju unutar učionice i izvan učionice na lokalnoj, nacionalnoj i globalnoj razini.

U prvom dijelu ovoga rada teorijski se razmatra koncept identiteta učitelja inog jezika, a u drugomu se predstavljaju rezultati provedenoga istraživanja kojim se želio istražiti profesionalni identitet učitelja francuskoga jezika u Republici Hrvatskoj. Zanimalo nas je mijenjaju li

${ }^{1}$ Društvenom paradigmom smatra se pristup istraživanju u koji se upisuju različiti teorijski pravci koje međusobno povezuje način konceptualizacije identiteta. Identitet se opisuje i istražuje kao višestruk, promjenjiv i dinamičan skup pojedinčevih značajki koji je ovisan o kontekstu te izgrađen i iskazan jezikom ili diskursom (vidi Block, 2007). 
učitelji francuskog jezika svoj profesionalni identitet ili ne mijenjaju, a ako mijenjaju, u kojoj je to mjeri i koji su razlozi tomu.

\section{Što podrazumijeva identitet učitelja inoga jezika?}

Pennington (1999) identitet učitelja inoga jezika određuje kao spoj osobnog identiteta i kolektivnog identiteta koji se, pak, odnosi na njegove profesionalne kompetencije. Korthagen (2004) u svome društveno-psihološkom modelu učiteljeva profesionalnoga identiteta navodi njegove dvije osnovne dimenzije: kognitivno-psihološku koja podrazumijeva učiteljevu misiju, identitet, uvjerenja i kompetencije te društvenu dimenziju koja, pak, uključuje učiteljevo ponašanje i okolinu. Prema Richardsovom (2006) modelu identitet učitelja inoga jezika čine tri njegova vida: diskursni identitet (engl. discourse identity), djelatni identitet (engl. situated identity) i prenosivi identitet (engl. transportable identity). Prvi se odnosi na učiteljevo diskursno razredno djelovanje (npr. vođenje i usmjeravanje razredne komunikacije), drugi na djelovanje koje proizlazi iz učiteljeve tradicionalne uloge (npr. prijenos znanja, praćenje i vrednovanje), a treći na pojedinčeva obilježja kao što su dob, spol, nacionalna pripadnost, uvjerenja, hobiji, dakle obilježja koja su prenosiva na svaki pojedinčev društveni identitet (npr. majka, supruga, odbojkašica).

Pennington i Richards (2016) nude sveobuhvatniji model prema kojemu identitet učitelja inoga jezika čini pet međudjelujućih vidova identiteta, proizašlih iz znanja i vještina koje čine okosnicu njegova zanimanja, a to su: jezični identitet vezan uz jezik poučavanja, profesionalni identitet, refleksivni identitet, kontekstualni identitet te identitet u međudjelovanju s učeničkim identitetima. Jezični identitet vezan uz jezik poučavanja (engl. language-related identity) odnosi se na učiteljevu ovladanost komunikacijskom jezičnom kompetencijom jezika koji poučava, njegov osobni doživljaj ovladanosti tom kompetencijom te utjecajem toga doživljaja na njegovo viđenje sebe kao učitelja. Na taj vid identiteta učitelja inih jezika neizvornih govornika, a ponekad i na njihov osjećaj manje vrijednosti, može utjecati i društveno uvriježeno mišljenje kako je najbolji učitelj inog jezika - izvorni govornik (vidi De Costa i Norton, 2017; Pennington i Richards, 2016). S tim u vezi Zheng (2017) navodi kako bi trebalo podupirati učiteljev transjezični identitet 
umjesto da ga se pokušava ukalupiti u identitet neizvornog govornika. Učiteljev profesionalni identitet (engl. disciplinary identity) odnosi se na njegova pedagoško-psihološko-didaktičko-metodička znanja i vještine potrebne za planiranje i izvođenje nastave. Istraživanja koja se bave ovim vidom učiteljeva identiteta pokušavaju, između ostalog, iz različitih teorijskih perspektiva odgovoriti na pitanja kao što su: na koji način stručno usavršavanje, njegov oblik i razlog te mogućnost certificiranja usvojenih znanja i vještina utječu na identitet učitelja inoga jezika (Mora, Trejo i Roux, 2015), zatim u kakvom su odnosu liberalna ideologija i stručno usavršavanje učitelja (Clarke i Phelan, 2015) ili, pak, kakva je veza između stručnoga usavršavanja učitelja i njihova moralnoga napretka (Miller, Morgan i Medina, 2017). Promjene ovoga vida učiteljeva identiteta nastaju sudjelovanjem u aktivnostima stručnoga usavršavanja. Refleksivni (engl. self-knowledge and awareness) i kontekstualni identitet (engl. context-related identity) međusobno su vrlo usko povezani: refleksivni identitet odnosi se na učiteljevo samovrednovanje općih kompetencija, a kontekstualni identitet na poznavanje vlastitih kompetencija vezanih za radno mjesto, vlastitih snaga i slabosti te na djelovanja usmjerena njihovome unapređenju. Učiteljev kontekstualni identitet povezan je i ovisan ne samo o radnim uvjetima mjesta na kojem radi, kao što su broj učenika u razredu, materijalna opremljenost razreda i potpora školske administracije, nego i o širem društvenom kontekstu u kojem radi i živi. S tim u vezi Norton (2016) navodi sljedeća pitanja na koja bi bilo potrebno pronaći odgovore: Kakva je veza učitelja s razrednom zajednicom, školskom institucijom i širom zajednicom? Kako se ta veza mijenjala kroz vrijeme i u različitim društvenim i obrazovnim kontekstima? Koje su učiteljeve želje za budućnost i kako one utječu na učiteljevo poučavanje? Na koji način politički sustavi, napose liberalna ideologija, utječu na poučavanje jezika i na učiteljev identitet? Kako na učitelja utječu državni ispiti i drugi oblici vanjskoga vrednovanja? Učiteljev identitet u međudjelovanju s učeničkim identitetima (engl. student-related identity) je, prema Pennington i Richards (2016), peti vid njegova identiteta, a odnosi se na razumijevanje učeničkih identiteta i razumijevanje vlastitoga utjecaja na njihove identitete. Naime, promjene u razumijevanju učenika i njegova identiteta zahtijevaju promjene i u razumijevanju učitelja i učiteljeva identiteta što je osobito vidljivo u odrednicama autora koji identitete istražuju u okviru društvene paradigme. Tako, primjerice, Kiely (2014) navodi da na oblikovanje identiteta inojezičnoga učitelja 
utječe jezik koji predaje, njegov profesionalni status, pedagoški pristup te sudjelovanje u različitim oblicima stručnoga usavršavanja, odnosno ulaganje u stručno usavršavanje. Primjerice, $u$ istraživanju koje je proveo Kiely (2012) pokazalo se kako se broj polaznika tečaja engleskog jezika znatno manje smanjivao nakon što je učiteljica ovladala znanjima o konceptu učenikova ulaganja te ih primijenila u praksi što joj je ujedno donijelo veliko zadovoljstvo i osjećaj uspješnosti.

Koncept ulaganja, izvorno osmišljen u kontekstu ovladavanja inim jezikom (vidi Norton-Peirce, 1995; Darvin i Norton, 2015), kao i drugi njemu slični i iz njega proizašli koncepti, u posljednje vrijeme počinje se upotrebljavati i kao istraživački koncept u kontekstu učitelja inoga jezika (vidi Norton, 2016). Norton $(2013,4)$ je identitet odredila kao »način na koji osoba razumije svoj odnos sa svijetom, način na koji je taj odnos oblikovan kroz vrijeme i prostor i način na koji osoba razumije svoje mogućnosti za budućnost«. Prema tome, učitelj inoga jezika trebao bi moći osobno procijeniti želi li u svoj učiteljski identitet ulagati ili, pak, ne, s obzirom na osobnu procjenu koristi ulaganja za svoju profesionalnu budućnost.

Na model ulaganja Bonny Norton velikim dijelom utjecala je društveno-kulturna teorija Lavea i Wengera (1991), teorija legitimnog rubnog sudjelovanja (engl. legitimate peripheral participation), u okviru koje se učenje konceptualizira kao "proces sudjelovanja u zajednici djelovanja, zajednici koju čini skupina osoba koje dijele određeni interes ili strast te $u$ redovitom međudjelovanju uče kako u tome biti što bolji« (Wenger i Wenger-Trayner, 2015, 1). Naime, prema Wengeru

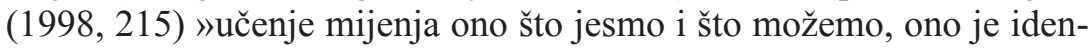
titetsko iskustvo« te je, prema tome, sudjelovanje zapravo učenje odnosno "proces postajanja, ili izbjegavanja postajanja određenom osobom, više nego jednostavna akumulacija vještina i znanja« (Pavlenko i Norton, 2007, 590). Zbog toga je sudjelovanje ključni koncept ovoga istraživanja.

\section{Metodologija istraživanja}

U ovome radu istražuje se profesionalni identitet učitelja francuskoga jezika u Republici Hrvatskoj. Konkretno, zanima nas mijenjaju li učitelji francuskog jezika svoj profesionalni identitet ili ne mijenjaju, a ako mijenjaju, u kojoj je to mjeri i koji su razlozi tomu. Također se že- 
ljelo istražiti postoji li statistički značajna razlika u osjećaju pripadnosti zajednici učitelja francuskoga jezika u Republici Hrvatskoj u odnosu na ispitivane nezavisne varijable (radno iskustvo, članstvo u Hrvatskoj udruzi učitelja francuskog jezika i status stranog jezika). Navedeni podatak činio se važnim s obzirom na vezu između identiteta i osjećaja pripadnosti određenoj zajednici.

U istraživanju je sudjelovalo 38 učitelja francuskoga jezika zaposlenih u javnom državnom obrazovnom sustavu² od toga 16 iz Dalmacije, 15 iz sjeverozapadne Hrvatske, 5 iz Istre i Kvarnera i 2 iz Slavonije. Većina sudionika (24) imala je više od 10 godina radnog iskustva, dok je manji broj sudionika (14) imao manje od 10 godina radnog iskustva. Od ukupnog broja sudionika, 21 učitelj bio je zaposlen u srednjoj školi, a ostalih $17 \mathrm{u}$ osnovnim školama. Većina sudionika (22) predavala je francuski jezik kao obvezni nastavni predmet, a 16 učitelja predavalo je francuski jezik kao izborni ili fakultativni nastavni predmet. Od ukupno 38 učitelja, 30 ih je bilo aktivnim članovima Hrvatske udruge profesora francuskoga jezika (dalje: HUPF).

Instrument istraživanja bio je upitnik konstruiran za potrebe ovoga istraživanja. Prvim dijelom upitnika prikupljeni su osnovni demografski podatci, a drugim dijelom specifični podatci vezani za istraživačka pitanja. U drugom dijelu upitnika korištene su petostupanjske skale kojima su ispitanici procjenjivali mjeru ili učestalost u kojoj ispitivani aspekti vrijede za njih osobno. Podatci su prikupljeni u svibnju 2018. godine u Zadru tijekom državnoga skupa učitelja i nastavnika francuskoga jezika. Sudjelovanje je bilo u potpunosti anonimno i dobrovoljno. S obzirom na broj sudionika i njihov udio u ukupnoj populaciji te utjecaj koji je na istraživačko pitanje imalo mjesto prikupljanja podataka, potrebno je istaknuti djelomičnu ograničenost reprezentativnosti dobivenih rezultata.

Postupak istraživanja obuhvaćao je postupke koji se inače koriste u istraživanjima ove vrste i to: osnovni matematičko-statistički postupci deskriptivne statistike kako bi se pregledno saželi i prikazali podatci te metoda izračunavanja statističke značajnosti razlika t-testom između različitih skupina ispitanika. Za obradu prikupljenih podataka korišten je JASP, program za statističku obradu podataka.

\footnotetext{
${ }^{2}$ Iako ne raspolažemo točnim podatcima o ukupnom broju učitelja francuskoga jezika u Republici Hrvatskoj zaposlenih u javnom sustavu, pretpostavka je kako je trenutno aktivno oko 150 učitelja francuskog jezika.
} 


\section{Rezultati i rasprava}

Ispitani učitelji francuskog jezika u Republici Hrvatskoj svoju komunikacijsku jezičnu kompetenciju procijenili su vrlo dobrom $(\mathrm{M}=4.132)$, baš kao i svoje nastavničke kompetencije $(\mathrm{M}=4.368)$. Očito je da imaju vrlo dobru predodžbu vlastitoga inojezičnoga i profesionalnoga identiteta.

Prema jednoj od motivacijskih teorija (Deci, 1971) podrijetlo poticaja na ulaganje u stručno usavršavanje odnosno učenje, a time i u promjenu identiteta, može biti unutarnje (npr. osobna želja za učenjem i promjenom) ili vanjsko (npr. zahtjevi nadređenih). S druge strane, prema modelu ulaganja (Darvin i Norton, 2015) podrijetlo poticaja uvijek je rezultat osobno procijenjene razlike između uloženog (npr. vremena, novca, truda) i potencijalno dobivenog (npr. ugleda, statusa, novca). Podatci o podrijetlu poticaja na stručno usavršavanje učitelja francuskog jezika prikazani su u Tablici 1.

Tablica 1. Podrijetlo poticaja na sudjelovanje u aktivnostima stručnog usavršavanja

\begin{tabular}{|l|c|c|c|c|c|}
\hline & $\begin{array}{c}\text { U vrlo } \\
\text { velikoj } \\
\text { mjeri }\end{array}$ & $\begin{array}{c}\text { U velikoj } \\
\text { mjeri }\end{array}$ & $\begin{array}{c}\text { U osred- } \\
\text { njoj mjeri }\end{array}$ & $\begin{array}{c}\text { U maloj } \\
\text { mjeri }\end{array}$ & $\begin{array}{c}\text { U vrlo } \\
\text { maloj } \\
\text { mjeri }\end{array}$ \\
\hline Unutarnji poticaj & $79 \%$ & $10.5 \%$ & $10.5 \%$ & $/$ & $/$ \\
\hline Vanjski poticaj & $23.7 \%$ & $28.9 \%$ & $18.4 \%$ & $15.8 \%$ & $13.2 \%$ \\
\hline $\begin{array}{l}\text { Razlika između } \\
\text { uloženog i dobivenog }\end{array}$ & $34.2 \%$ & $23.7 \%$ & $34.2 \%$ & $5.3 \%$ & $2.6 \%$ \\
\hline
\end{tabular}

Rezultati ovoga istraživanja pokazali su kako su ispitani učitelji francuskog jezika u najvećoj mjeri unutarnje motivirani na sudjelovanje u aktivnostima stručnoga usavršavanja. Iz toga proizlazi da žele učiti i da su spremni i sposobni samovrednovati te dobrovoljno usmjeravati i unapređivati, odnosno mijenjati svoj profesionalni identitet. Takav rezultat potvrđuje pretpostavku prema kojoj »inojezični učitelji obično žele djelovati, žele da ih se smatra profesionalcima te su željni unapređivanja svog nastavnog djelovanja i učiteljskih identiteta kako bi dobili potrebne profesionalne kompetencije« (Miller, Morgan, i Medina, 2017, 102) zbog čega se često, kako kažu Clarke i Phelan $(2015,6)$, dobrovoljno uključuju u aktivnosti »nemilosrdnog i neprestanog samo- 
razvoja« kako bi postigli što veći uspjeh u učionici. Iz Tablice 1 vidljivo je kako na odluku više od polovine ispitanih učitelja u vrlo velikoj i velikoj mjeri utječe njihova osobna procjena uloženoga i dobivenoga. Takav kritičan doživljaj stručnih usavršavanja organizatorima stručnih usavršavanja trebao bi služiti kao poticaj na ponudu što kvalitetnijih sadržaja, a učiteljima omogućiti dobar izbor u sve većoj globalnoj ponudi e-stručnih usavršavanja.

Rezultati su, očekivano, pokazali i da ispitane učitelje francuskog jezika na sudjelovanje u aktivnostima stručnoga usavršavanja potiču i vanjski čimbenici. Naime, u Republici Hrvatskoj zakonima i pravilnicima propisano je da odgojno-obrazovni radnici u osnovnoj i srednjoj školi imaju pravo i obvezu trajno se stručno osposobljavati i usavršavati programima koje je odobrilo nadležno Ministarstvo znanosti i obrazovanja. Prema tome, svi učitelji dužni su tijekom svoje karijere mijenjati svoj profesionalni identitet, bez obzira na osobnu procjenu koristi. Međutim, analiza postojećeg sustava stručnog usavršavanja odgojno-obrazovnih radnika (Roeders, 2013) utvrdila je, između ostalog, da u Republici Hrvatskoj ne postoji sustav akreditiranja svih programa stručnog usavršavanja zbog čega nisu jasni kriteriji priznavanja u svrhu napredovanja potvrda o sudjelovanju u programima drugih pružatelja te da u ponudi postoje različita stručna usavršavanja drugih pružatelja koja nisu registrirana u nacionalnomu sustavu, od kojih se većina naplaćuje, što često ograničava mogućnosti sudjelovanja zbog čega odgojno-obrazovni radnici pohađanje takvih programa plaćaju vlastitim sredstvima ili sredstvima ustanove. Osim toga, ne postoji pravilnik prema kojemu je škola obvezna učiteljima platiti sudjelovanje na stručnomu usavršavanju, što može podrazumijevati i troškove prijevoza i dnevnica. Prema tomu, učitelji mogu birati aktivnosti u koje žele ulagati svoje vrijeme, ali zbog financijskog ograničenja samo djelomično.

U tablici koja slijedi prikazana je čestota njihova sudjelovanja u različitim oblicima stručnoga usavršavanja. 
Tablica 2. Oblici i čestota ulaganja u profesionalni identitet

\begin{tabular}{|l|c|c|c|c|c|}
\hline & Vrlo često & Često & Povremeno & Rijetko & Nikad \\
\hline $\begin{array}{l}\text { Školska stručna } \\
\text { usavršavanja }\end{array}$ & $84.3 \%$ & $13.2 \%$ & $/$ & $2.5 \%$ & $/$ \\
\hline $\begin{array}{l}\text { Županijska i } \\
\text { međužupanijska stručna } \\
\text { usavršavanja }\end{array}$ & $81.6 \%$ & $10.5 \%$ & $5.3 \%$ & $2.6 \%$ & $/$ \\
\hline Državni stručni skupovi & $63.2 \%$ & $18.4 \%$ & $10.5 \%$ & $7.9 \%$ & $/$ \\
\hline E-učenje & $15.8 \%$ & $18.4 \%$ & $13.2 \%$ & $28.9 \%$ & $23.7 \%$ \\
\hline Stručna literatura & $18.4 \%$ & $34.2 \%$ & $28.9 \%$ & $13.2 \%$ & $5.3 \%$ \\
\hline
\end{tabular}

Promotre li se ukupni rezultati prikazani u Tablici 2, očito je kako se ispitani učitelji francuskoga jezika najčešće usavršavaju na školskim i županijskim, odnosno međužupanijskim stručnim skupovima. Takvi rezultati nisu iznenađujući s obzirom na organizacijsku i financijsku pristupačnost takvih oblika usavršavanja. Međutim, brojku koja odražava čestotu njihova sudjelovanja na državnim skupovima potrebno je uzeti s dozom opreza jer je ovo istraživanje provedeno tijekom državnoga skupa što znači da uzorak nije bio reprezentativan. Masovni otvoreni online tečajevi (eng. MOOC-massive online open course) zbog svojih brojnih prednosti nad fizičkim tečajevima postaju sve popularniji oblik stručnoga usavršavanja u cijelomu svijetu, a osobito su pogodni za usavršavanje učitelja inih jezika jer im omogućuju komunikaciju s izvornim govornicima te pristup materijalima izrađenima u zemljama polaznog jezika i kulture, kako za razvoj inojezičnog, tako i za razvoj profesionalnog identiteta. ${ }^{3}$ Stoga iznenađuje što više od polovine ispitanih učitelja francuskoga jezika ne sudjeluje u takvim oblicima učenja. Međutim, određenu nevoljkost za sudjelovanje u aktivnostima e-učenja moguće je objasniti učiteljevom nespremnošću za promjenu, otporom promjenama koje diktira suvremeno društvo ili pak nedovoljnom informiranošću. Konačno, rezultati su pokazali da čak $47.4 \%$ ispitanih učitelja povremeno, rijetko ili nikad ne konzultira stručnu literaturu.

${ }^{3}$ U školskoj godini 2018./2019. na online platformi FunMooc za učitelje francuskoga jezika ponuđeni su brojni e-tečajevi od kojih spominjemo samo neke: Réalité Virtuelle et pratiques pédagogiques innovantes (Université de Lyon), Enseigner et former avec le numérique en langues, Université Grenoble Alpes, Moi, prof de FLE, Université de Liège, Pratiques de l'enseignement de la prononciation en FLE, Université Toulouse. 
Iako možemo pretpostaviti da na to dijelom utječe nedostupnost stručne literature na francuskomu jeziku u RH, svakako nam se čini da bi $\mathrm{u}$ jednom od budućih istraživanja bilo važno istražiti upravo taj oblik stručnoga usavršavanja učitelja inih jezika, ali i ostalih učitelja.

Osim sudjelovanja u aktivnostima stručnoga usavršavanja, zanimalo nas je i kako učitelji percipiraju utjecaj sudjelovanja u takvim aktivnostima na promjenu svog učiteljskog djelovanja. Rezultati su nas vrlo ugodno iznenadili jer su pokazali kako većina ispitanih učitelja smatra da stručna usavršavanja u vrlo velikoj i velikoj mjeri utječu na promjenu njihovih djelovanja (84.2\%).

Također, zanimalo nas je koliko često sudjeluju u frankofonskim zajednicama, bilo u lokalnoj sredini (npr. Francuski institut, HUPF, osobni kontakti s frankofonima), bilo na nacionalnoj ili globalnoj razini putem internetskih stranica s medijskim ili kulturnim sadržajima (npr. Culturethèque), odnosno putem društvenih mreža (vidi Tablicu 3).

Tablica 3. Čestota sudjelovanja u frankofonskim zajednicama

\begin{tabular}{|l|c|c|c|c|c|}
\hline & Vrlo često & Često & Povremeno & Rijetko & Nikad \\
\hline $\begin{array}{l}\text { Čestota sudjelovanja u } \\
\text { frankofonskim } \\
\text { zajednicama }\end{array}$ & $18.4 \%$ & $18.4 \%$ & $21.1 \%$ & $15.8 \%$ & $26.3 \%$ \\
\hline
\end{tabular}

Rezultati su pokazali kako $18.4 \%$ učitelja vrlo često sudjeluje u frankofonskim zajednicama, $18.4 \%$ često, $21.1 \%$ povremeno, $15.8 \%$ rijetko te $26.3 \%$ vrlo rijetko. Ovi rezultati zasigurno jednim svojim dijelom odražavaju nemogućnost hrvatskih učitelja da u svojoj lokalnoj zajednici sudjeluju u frankofonskim zajednicama jer takve mogućnosti naprosto nema. Međutim, brojne su mogućnosti povezivanja koje u današnje vrijeme omogućuje digitalna tehnologija. Više je mogućih objašnjenja za to što gotovo polovica hrvatskih učitelja francuskoga jezika vrlo rijetko ili rijetko sudjeluje u takvim zajednicama, primjerice nedovoljna digitalna pismenost ili nedovoljan interes za pripadanjem frankofonskim zajednicama. Svakako bi u nekome od sljedećih istraživanja bilo poželjno dodatno istražiti osobne razloge učitelja koji se odlučuju ne sudjelovati u frankofonskim zajednicama. Iako se u ovom istraživanju nisu istražili razlozi nesudjelovanja u različitim frankofonskim zajednicama, istraženi su razlozi učiteljeva nesudjelovanja u 
aktivnostima stručnoga usavršavanja. U upitniku su ispitanicima bile ponuđene četiri kategorije čimbenika koji bi ih mogli potaknuti na nesudjelovanje (Tablica 4).

Tablica 4. Razlozi za nesudjelovanje u aktivnostima stručnog usavršavanja

\begin{tabular}{|l|c|c|c|c|c|}
\hline & $\begin{array}{c}\text { U vrlo } \\
\text { velikoj mjeri }\end{array}$ & $\begin{array}{c}\text { U velikoj } \\
\text { mjeri }\end{array}$ & $\begin{array}{c}\text { U osrednjoj } \\
\text { mjeri }\end{array}$ & $\begin{array}{c}\text { U maloj } \\
\text { mjeri }\end{array}$ & $\begin{array}{c}\text { U vrlo } \\
\text { maloj mjeri }\end{array}$ \\
\hline $\begin{array}{l}\text { Unutarnji } \\
\text { čimbenici }\end{array}$ & $12.2 \%$ & $5.3 \%$ & $12.2 \%$ & $14.8 \%$ & $55.5 \%$ \\
\hline $\begin{array}{l}\text { Vanjski } \\
\text { čimbenici }\end{array}$ & $5.4 \%$ & $18.4 \%$ & $21.1 \%$ & $21.1 \%$ & $34.2 \%$ \\
\hline $\begin{array}{l}\text { Organizacijski } \\
\text { čimbenici }\end{array}$ & $18.4 \%$ & $31.5 \%$ & $13.2 \%$ & $13.2 \%$ & $23.7 \%$ \\
\hline $\begin{array}{l}\text { Financijski } \\
\text { čimbenici }\end{array}$ & $26.3 \%$ & $18.4 \%$ & $10.5 \%$ & $13.2 \%$ & $31.6 \%$ \\
\hline
\end{tabular}

Kako se iz Tablice 4 može uočiti, na nesudjelovanje ispitanih učitelja francuskog jezika u aktivnostima stručnog usavršavanja najviše utječu konkretni organizacijski i financijski čimbenici, a najmanje unutarnji čimbenici. Takvi rezultati u skladu su s rezultatima prikazanima u Tablici 1. Prema tome, na nesudjelovanje se učitelji ne odlučuju zbog nedostatka želje za promjenom, zbog želje za ostankom na rubu zajednice djelovanja ili zbog želje za pružanjem otpora (vidi Norton, 2001), već zbog nemogućnosti za promjenu koja je najčešće posljedica nedovoljne i neodgovarajuće obrazovne politike.

Što se tiče osjećaja pripadnosti zajednici učitelja francuskoga jezika u Republici Hrvatskoj koji je prema Lave i Wenger (1991) ključan za razumijevanje identiteta, u ovom istraživanju pokazalo se kako razlike postoje samo u odnosu na sve tri varijable: iskustvo, članstvo u Hrvatskoj udruzi profesora francuskog jezika i status jezika. Podatci su prikazani u Tablici 5. 
Tablica 5. Analiza skupina s obzirom na osjećaj pripadnosti zajednici učitelja francuskog jezika u Republici Hrvatskoj

\begin{tabular}{|c|c|c|c|c|}
\hline Nezavisna varijabla & $\mathbf{t}$ & df & $\mathbf{p}$ & $\mathbf{M}$ \\
\hline $\begin{array}{l}\text { Radno iskustvo }>10 \\
\text { godina }\end{array}$ & \multirow{2}{*}{-3.709} & \multirow{2}{*}{36.00} & \multirow{2}{*}{.001} & 3.143 \\
\hline $\begin{array}{l}\text { Radno iskustvo }<10 \\
\text { godina }\end{array}$ & & & & 4.417 \\
\hline Član HUPF-a & \multirow{2}{*}{2.766} & \multirow{2}{*}{36.00} & \multirow{2}{*}{.009} & 4.2 \\
\hline Nije član HUPF-a & & & & 3.0 \\
\hline FJ - obvezni predmet & \multirow{2}{*}{1.426} & \multirow{2}{*}{36.00} & \multirow{2}{*}{0.163} & 4.190 \\
\hline $\begin{array}{l}\text { FJ - izborni ili } \\
\text { fakultativni predmet }\end{array}$ & & & & 3.647 \\
\hline
\end{tabular}

$t$ - koeficijent varijacije uzorka; $d f$ - broj stupnjeva slobode; $p$ - stupanj značajnosti razlike; $M$ - aritmetička sredina

Kao što je vidljivo u gornjoj tablici, utvrđena je statistički značajna razlika između skupine učitelja koji imaju manje od 10 godina radnoga iskustva u nastavi francuskoga jezika i onih koji imaju više od 10 godina radnoga iskustva u poučavanju francuskoga jezika. Rezultati pokazuju kako značajno veću pripadnost zajednici učitelja francuskoga jezika u RH, očekivano, doživljavaju učitelji s više godina radnoga iskustva. Očekivana statistički značajna razlika također je utvrđena i između skupine učitelja koji su članovi HUPF-a i onih koji nisu članovi navedene udruge: članovi HUPF-a doživljavaju veću pripadnost zajednici učitelja francuskoga jezika od onih učitelja koji to nisu. Rezultati su također pokazali kako manju pripadnost zajednici učitelja francuskoga jezika osjećaju učitelji koji francuski jezik predaju kao izborni ili fakultativni predmet od onih koji francuski jezik predaju kao obvezni predmet. Navedeni rezultat nije neočekivan. Naime, dio učitelja koji predaje francuski jezik kao izborni predmet zbog smanjene satnice ponekad predaje i neki drugi predmet ili pak imaju povećane ostale školske obveze (izvannastavne aktivnosti, razrednički poslovi i dr.). Ukoliko je drugi predmet koji predaju u statusu obveznoga, mogućim se čini da ti učitelji veću pripadnost osjećaju drugoj zajednici, kako zbog činjenice da u toj 
zajednici provode više vremena, tako i zbog činjenice da se u toj zajednici osjećaju sigurnijima, društveno i materijalno.

\section{Zaključak}

Ovim istraživanjem želio se istražiti profesionalni identitet učitelja francuskoga jezika u Republici Hrvatskoj, odnosno načini na koje učitelji francuskog jezika mijenjaju svoj identitet te razlozi zbog kojih ga mijenjaju ili, pak, ne mijenjaju. Rezultati su pokazali kako ispitani učitelji svoj učiteljski identitet najčešće mijenjaju sudjelujući na školskim i županijskim, odnosno međužupanijskim stručnim usavršavanjima, a najmanje sudjelovanjem u organiziranim e-tečajevima. Pritom se osobito važnim čini sljedeći nalaz: učitelji smatraju kako promjene proizašle iz stručnih usavršavanja utječu na promjenu njihovog djelovanja u nastavnome procesu. Glavnim razlogom za sudjelovanje u aktivnostima stručnoga usavršavanja pokazao se njihov unutarnji poticaj, dok su se glavnim razlogom za nesudjelovanje u takvim aktivnostima pokazali financijski čimbenici.

Rezultati ovog istraživanja djelomično su potvrdili i postavljenu hipotezu: Postoji statistički značajna razlika u osjećaju pripadnosti zajednici učitelja francuskoga jezika u Republici Hrvatskoj u odnosu na ispitivane nezavisne varijable. Naime, izračunom t-testa utvrđeno je kako se osjećaj pripadnosti zajednici učitelja francuskoga jezika razlikuje među učiteljima samo s obzirom na njihovo radno iskustvo, na članstvo u Hrvatskoj udruzi profesora francuskoga jezika i na status jezika koji predaju. Konkretno, dulje radno iskustvo, članstvo u udruzi i obvezni status jezika pokazali su se faktorima koji značajno utječu na osjećaj pripadnosti zajednici učitelja francuskoga jezika. Prema teoriji legitimnog rubnog sudjelovanja (Lave i Wenger, 1991), važnost osjećaja pripadnosti zajednici koji se, između ostalog, temelji na sudjelovanju u istoj, važan je iz više razloga: sudjelovanjem u zajednici mlađi članovi uče od starijih, a stariji djeluju kao mentori mlađima te na taj način istovremeno mijenjaju sve vidove svojega učiteljskoga identiteta te pridonose promjeni drugih. Osim toga, sudjelovanje u zajednicama djelovanja svim članovima omogućuje samovrednovanje posredstvom usporedbe s drugim članovima što potencijalno djeluje kao poticaj za unapređenje svojih znanja i vještina. Nadalje, mlađi članovi temeljem preporuka svojih mentora, učitelja s dugogodišnjim nastavnim iskustvom ili etabliranih članova zajednice, mogu napredovati i na hijerar- 
hijskoj ljestvici u svojoj struci, kako unutar zajednice, tako i izvan nje. Iz toga je moguće pretpostaviti da osjećaj pripadnosti može utjecati i na, primjerice, nastavničke kompetencije ili pak osjećaj profesionalnog zadovoljstva, a u konačnici i na kvalitetu nastavnoga procesa, što bi bilo vrlo zanimljivo ispitati u nekome od sljedećih istraživanja.

Identitet učitelja inoga jezika svakako je nedovoljno istražen koncept na području Republike Hrvatske, osobito u okviru društvene istraživačke paradigme. Stoga je ovo istraživanje važno jer je omogućilo jedan drukčiji pogled na učitelja inoga jezika, ali i pružilo informacije o tome kako nastaviti i poboljšati buduća istraživanja u ovome ili nekome sličnome smjeru. Naime, bilo bi dobro istražiti i druge vidove učiteljeva identiteta što bi omogućilo potpuniju sliku učiteljskoga identiteta, kao jedne od sastavnica pojedinčevog društveno-kulturnog identiteta. Pritom bi se trebalo više osloniti na kvalitativne istraživačke metode, poput dnevnika ili intervjua. Također, bilo bi važno pokušati istražiti međuodnos ove i drugih sastavnica učiteljeva identiteta, primjerice međudjelovanje učiteljskog identiteta i drugih vidova njegova društvenog identiteta. Rezultati ovoga istraživanja mogli bi koristiti i kao znanstvena potkrepa društvenoj slici učitelja kao osobe željne unapređivanja svojih profesionalnih kompetencija. Osim toga, rezultati mogu poslužiti učiteljima i kao poticaj za učlanjenje u Hrvatsku udrugu profesora francuskoga jezika ili druge zajednice frankofonskih govornika što se u okviru u ovom istraživanju primijenjene teorije smatra važnim za pozitivne identitetske promjene koje se pak mogu pozitivno odraziti na razredno djelovanje, ali i na širu društvenu zajednicu.

\section{Literatura}

Block, David (2007), Second Language Identities, New York: Bloomsbury Publishing.

Breka, Olenka i Petravić, Ana (2015), »Foreign language teachers and the intercultural dimension in primary education «, Croatian Journal of Education, Vol. 17; sp. ed. No. 2/2015, str. 27-41. doi: https://doi.org/10.15516/cje.v17i0.1529

Cindrić, Ivana; Andraka, Marija i Bilić-Štefan, Milka (2014), »Kompetencije učitelja engleskog jezika iz perspektive studenata-učitelja: percepcija važnosti i stjecanja «, Croatian Journal of Education, 16(1), str. 11-42.

Clarke, Matthew (2008), Language Teacher Identities: Co-Constructing Discourse and Community, Clevedon: Multilingual Matters.

doi: https://doi.org/10.21832/9781847690838 
Clarke, Matthew i Phelan, Anne (2015), »The power of negative thinking in and for teacher education «, Power and Education, 7(3), str. 257-271. doi: https://doi.org/10.1177/1757743815607025

Darvin, Ron i Norton, Bonny (2015), »Identity and a model of investment in applied linguistics «, Annual Review of Applied Linguistics, 35, str. 36-56. doi: 10.1017/ S0267190514000191. doi: https://doi.org/10.1017/S0267190514000191

De Costa, Peter i Norton, Bonny (2017), »Introduction: identity, transdisciplinarity, and the good language teacher«, The Modern Language Journal, 101, supplement, str. 3-14. doi: https://doi.org/10.1111/modl.12368

Deci, Edward L. (1971), »Effects of externally mediated rewards on intrinsic motivation «, Journal of Personality and Social Psychology, 18(1), str. 105-115. doi: 10.1037/h0030644. doi: https://doi.org/10.1037/h0030644

Duff, Patricia (2012), »Identity, agency and second language acquisition«, u: Susan M. Gass i Alice Mackey (ur.), The Routledge Handbook of Second Language Acquisition, London/New York: Routledge, str. 410-426.

Duff, Patricia i Uchida, Yuko (1997), »The negotiation of teachers' sociocultural identities and practices in postsecondary EFL classrooms «, TESOL Quarterly, 31(3), str. 451-486. doi: https://doi.org/10.2307/3587834

Kanno, Yasuko i Stuart, Christian (2011), »Learning to become a second language teacher: Identities-in-practice«, The Modern Language Journal, 95(2), str. 236-252. doi: https://doi.org/10.1111/j.1540-4781.2011.01178.x

Kiely, Richard (2012), »Teacher learning and professional identity: Making the connection«, u: Strengthening English Language Through professional Development. Proceedings of the 2011 ELTC-TED Conference, Kuala Lumpur, Malaysia: ELTC.

Kiely, Richard (2014), »English language teacher identity: A framework for teacher learning and professional development«, u: David Evans (ur.), Language and Identity: Discourse in the World, London: Bloomsbury, str. 207-228.

Knežević, Željka (2017), »Priprema li inicijalno obrazovanje učitelje njemačkog i engleskog jezika za razvoj višejezične i međukulturne kompetencije učenika? - Analiza studijskih programa«, Hrvatski časopis za odgoj i obrazovanje, 19 (Sp.Ed.2), str. 13-33. doi: https://doi.org/10.15516/cje.v19i0.2612

Korthagen, Fred A. J. (2004), »In search of the essence of a good teacher: Towards a more holistic approach in teacher education«, Teaching and Teacher Education, 20(1), str. 77-97. doi: https://doi.org/10.1016/j.tate.2003.10.002

Lave, Jean i Wenger, Etienne (1991), Situated learning: Legitimate peripheral participation, London: Cambridge University Press. doi: https://doi.org/10.1017/CBO9780511815355 
Lujić, Rea (2017), »Ulaganje u ini jezik, jedan od preduvjeta učenja inog jezika i oblikovanja društveno-kulturnog identiteta«, Strani jezici, 45, 1, str. 40-53.

Lujić, Rea (2018), »Classroom participation as a performative act of language learners' identiy construction «, Journal of Language and Cultural Education, 6(3), str. 72-84. doi: https://doi.org/10.2478/jolace-2018-0025

Menard-Warwick, Julia (2013), English Language Teachers on the Discursive Faultines: Identities, Ideologies and Pedagogies, Bristol: Multilingual Matters. doi: https://doi.org/10.21832/9781783091119

Miller, Jennifer (2004), »Identity and language use: The politics of speaking ESL in schools «, u: Aneta Pavlenko i Adrian Blackledge (ur.), Negotiation of Identities in Multilingual Contexts, Clevedon: Multilingual Matters, str. 290-315. doi: https://doi.org/10.21832/9781853596483-013

Miller, Elisabeth R; Morgan, Brian i Medina, Adrian L. (2017), »Exploring teacher identity work as ethical self-formation «, The Modern Language Journal, str. 91-105. doi: https://doi.org/10.1111/modl.12371

Mora, Alberto; Trejo, Pauline i Roux, Ruth (2014), »English language teachers' professional development and identities «, PROFILE Issues in Teachers' Professional Development, 16(1), str. 49-62. doi: https://doi.org/10.15446/profile.v16n1.38153

Norton-Peirce, Bonny (1995), »Social identity, investment and language learning «, TESOL Quarterly, 29(1), str. 9-31. doi: 10.2307/3587803. doi: https://doi.org/10.2307/3587803

Norton, Bonny (2001), »Non-participation, imagined communities, and the language classroom «, u: Michael P. Breen (ur.), Learner Contributions to Language Learning: New Directions in Research, Harlow: Pearson Education, str. 159-171.

Norton, Bonny (2013), Identity and Language Learning: Extending the Conversation, Bristol/ Buffalo/Toronto: Multilingual Matters. doi: https://doi.org/10.21832/9781783090563

Norton, Bonny (2016), »Learner investment and language teacher identity«, u: Gary Barkhuizen (ur.), Reflections on Language Teacher Identity Research, New York: Routledge, str. 80-86.

Norton, Bonny i Toohey, Kelleen (2011), »Identity, language learning and, social change «, Language Teaching, 44(4), str. 412-446. doi: https://doi.org/10.1017/S0261444811000309

Pavlenko, Aneta (2003), »'I never knew I was a bilingual': Reimagining teacher identities in TESOL «, Journal of Language, Identity, and Education, 2(4), str. 251-268. doi: https://doi.org/10.1207/S15327701JLIE0204_2

Pavlenko, Aneta i Blackledge, Adrian (2004), »Introduction: New theoretical approaches to the study of negotiation of identities in multilingual contexts «, $\mathrm{u}$ : 
Aneta Pavlenko i Adrian Blackledge (ur.), Negotiation of Identities in Multilingual Contexts, Bristol: Multilingual Matters, str. 1-33.

doi: https://doi.org/10.21832/9781853596483-003

Pavlenko, Aneta i Norton, Bonny (2007), »Imagined communities, identity, and English language learning «, u: Jim Cummins i Chris Davison (ur.), International Handbook of English Language Teaching, Springer International Handbooks of Education, 15, Boston, MA: Springer, str. 669-680.

doi: https://doi.org/10.1007/978-0-387-46301-8_43

Pennington, Martha C. (1999), »Rules to break and rules to play by: Implications of different conceptions of teaching for language teacher development «, u: Hugh Trappes i Alastair A. Pennycook (ur.), Critical Applied Linguistics: A Critical Introduction, Mahwah, NJ: Lawrence Erlbaum Associates, str. 46-73.

Pennington, Martha C. i Richards, Jack C. (2016), »Teacher identity in language teaching: Integrating personal, contextual, and professional factors «, RELC Journal, 47(1), str. 5-23. doi: https://doi.org/10.1177/0033688216631219

Petravić, Ana (2015), »Interkulturelle Kompetenz aus der Sicht der Fremdsprachenlehrkräfte. Auf dem Weg zu einem neuen professionellen Profil«, u: Gehrmann, Siegfried, Helmchen, Jürgen, Krüger-Potratz, Marianne i Ragutt, Frank (ur.), Bildungskonzepte und Lehrerbildung in europäischer Perspektive, Münster: Waxmann, str. 171-203.

Petravić, Ana i Šenjug Golub, Ana (2016), »Entwicklung der interkulturellen Kompetenz im Unterricht Deutsch als Fremdsprache. Eine empirische Untersuchung zum interkulturell orientierten Kompetenzprofil der DaF-Lehrkräfte«, Zeitschrift für interkulturellen Fremdsprachenunterricht online 21, 1/2016, str. 245-262. Dostupno na: http://tujournals.ulb.tu-darmstadt.de/index.php/ zif/article/view/805 [18. 10. 2019.]

Reeves, Jenelle (2009), »Teacher investment in learner identity«, Teaching and Teacher Education, 25, str. 34-41.

doi: https://doi.org/10.1016/j.tate.2008.06.003

Richards, Keith (2006), »'Being the teacher': Identity and classroom conversation«, Applied Linguistics, 27(1), str. 51-77.

doi: https://doi.org/10.1093/applin/ami041

Roeders, Paul (2013), Analiza postojećeg AZOO sustava stručnog usavršavanja odgojno-obrazovnih radnika i procjene potreba za stručnim usavršavanjem odgojno obrazovnih radnika, Zagreb: Agencija za odgoj i obrazovanje. Dostupno na: http://www.azoo.hr/images/pkssuor_dokumenti/130429_C1_ Analiza_AZOO_INSETT_system_TNA_fin_compl_HR.pdf [29. 5. 2019.]

Stranger-Johannessen, Espen i Norton, Bonny (2017), »The African storybook and language teacher identity in digital times«, The Modern Language Journal, 101, str. 45-60. doi: 10.1111/modl.12374.

doi: https://doi.org/10.1111/modl.12374 
Varghese, Manka; Morgan, Brian; Johnston, Bill i Johnson Kimberly A. (2005), »Theorizing language teacher identity: Three perspectives and beyond «, Journal of Language, Identity, and Education, 4(1), str. 21-44. doi: https://doi.org/10.1207/s15327701jlie0401_2

Vrhovac, Yvonne i Berlengi, Vedrana (2010), »Nastavnikove uloge pri razvijanju učenikove samostalnosti«, u: Vučo Julijana i Biljana Milatović (ur.), $A u$ tonomija učenika i nastavnika u nastavi jezika i književnosti, Nikšić: Filozofski fakultet Nikšić, str. 250-270.

Wenger, Etienne (1998), Communities of Practice: Learning, Meaning and Identity, London: Cambridge University Press.

doi: https://doi.org/10.1017/CBO9780511803932

Wenger, Etienne i Wenger-Trayner, Beverly (2015), Introduction to Communities of Practice: A Brief Overview of the Concept and Its Uses. Dostupno na: http:// wenger-trayner.com/introduction-to-communities-of-practice/ [29. 5. 2019.]

Zheng, Xuan (2017), »Translingual identity as pedagogy: International teaching assistants of English in college composition classrooms «, The Modern Language Journal, 101(S1), str. 29-44. doi: https://doi.org/10.1111/modl.12373

\title{
THE PROFESSIONAL IDENTITY OF FRENCH LANGUAGE TEACHERS IN CROATIA
}

\author{
Rea Lujić
}

The identity of foreign language teachers is an under-researched concept in Croatia. This paper thus focuses on this concept foremost from a theoretical position, followed by a description of the results of research into the professional identity of French teachers in Croatia. The research considers whether French teachers change their professional identity or not, and if they do, to which extent and for what reasons. The results show that teachers most often change their teaching identity by participating in local professional training courses, and least often by participating in organised e-courses. The main reason for participating in professional training activities proved to be internal motivation, while the main reason for not participating proved to be financial factors. A longer work history, membership in the Croatian Association of French Language Teachers, and status as a compulsory language proved to be statistically significant factors influencing feelings of belonging to the community of French teachers in Croatia.

Key words: Croatia, identity of foreign language teachers, French language teachers, investment, professional training, participation 